\title{
Stakeholder perception on the Sea Turtle conservation in the Gili Matra Tourism Area, Lombok, West Nusa
}

\section{Tenggara}

\author{
Ahmad Jupri (corresponding author) \\ Department of Biology, Faculty of Mathematics and Natural \\ Sciences, Mataram University, Majapahit Street 62, 83125, \\ Mataram, West Nusa Tenggara \\ juprizikril@gmail.com
}

\section{Hilman Ahyadi}

Department of Biology, Faculty of Mathematics and Natural Sciences, Mataram University, Majapahit Street 62, 83125, Mataram, West Nusa Tenggara

\author{
Baiq Riyan Anggriani Putri \\ Department of Biology, Faculty of Mathematics and Natural \\ Sciences, Mataram University, Majapahit Street 62, 83125, \\ Mataram, West Nusa Tenggara
}

\author{
Yuliadi Zamroni \\ Department of Biology, Faculty of Mathematics and Natural \\ Sciences, Mataram University, Majapahit Street 62, 83125, \\ Mataram, West Nusa Tenggara
}

\section{Abstract}

The conservation of sea turtles in a nature-based tourism area is significant to enhance sustainability of the sea turtle population in the wild. Small islands in Lombok Island chains, the Gili Matra, are one of the significant habitats for turtles, and the island is recognized as one of the islands with fastest tourism growth in Indonesia. The research aims to explore the stakeholders' perspectives in sea turtle conservation in Gili Matra, Lombok. Focus group discussion was implemented to identify the stakeholder perspective. Literature survey was carried out to generate related data concerning sea turtle population and its habitat quality in Gili Matra. The result of this study indicates that stakeholders can identify three species of sea turtle in Gili Matra waters, namely the green sea turtle (Chelonia mydas), the Hawksbill Turtle (Eretmochelys imbricate), and the ridley sea turtle (Lepydochely olivacea). Stakeholders state that between 1990 and 2017, there was reduction in the population size in Gili Matra. Factors related to the decrease of population in Gili Matra include decrease of habitat quality and human activity. Some recommendations were made, including increasing socialization and campaign, providing tools and facility to support conservation action, controlling unsustainable practice of fish collection, strengthening the implementation of regulation, and providing training and technical assistance to the local community and local office. 


\section{Keywords}

Sea turtle, stakeholder-based conservation, wildlife tourism

\section{Introduction}

Indonesian waters are an important habitat for the sea turtle, the most threatened marine reptile on Earth. A global survey indicated that the Indonesian water contains numerous species of marine turtles. So far, six species of the sea turtle found in Indonesian water, including the leatherback turtle (Dermochelys coriacea), the green turtle (Chelonia mydas), the loggerhead turtle (Caretta caretta), the flat back turtle (Natator depressa), the hawksbill sea turtle (Eretmochelys imbricate), and the olive ridley sea turtle (Lepidochelys olivacea). All of the population of these species has been reported to be decreasing. Indonesian waters play an important role as habitat and movement corridors of six species of the sea turtles (Nuitja, 1992; Halim, et al., 2001; Shanker and Pilcher, 2003; Chaloupka, et al., 2004).

In developing countries, the sea turtle has an important position in human culture. In many cases, sea turtles have considerable economic value, and in many local markets in coastal area, the sea turtle has been sold as a significant commodity. The economic value of the sea turtle leads to illegal poaching of species in the wild. Scholars point out that poaching was carried out by local inhabitants of a nearby village in the coastal area, especially in area with an abundant sea turtle population. Poaching the sea turtle in developing countries has been reported as complicated problems. Sea turtle meat, eggs, and shells are the main commodity in many black markets (Mack, 1983; Rene, 1990; Barr, 2001).

An increase in poaching of sea turtles has been reported to contribute to the decrease in their population. The decrease of the global population of sea turtles has been viewed as a crucial issue in global biodiversity programs. Numerous studies and discussions have been conducted to evaluate the recent status of the sea turtle. Most of the studies confirm that a comprehensive approach with stakeholder support was an important strategy in sea turtle conservation (Nuitja, 1992; Formia, et al., 2003). Sea turtle status in Indonesia is one of the focus for the global conservation program. According to scholars, the combination of high-level marine biodiversity and increase of demand of meat, eggs and shell very complicated. Comprehensive research is required to design a proper strategy for sea turtle conservation, including biological and social fields. The involvement of stakeholders in sea turtle conservation has been identified as crucial(Barr, 2001; Shanker and Pilcher, 2003; Suganuma, et al., 2005; Gjertsen and Niesten, 2010; Hakim, 2017).

The Gili Matra waters in Lombok Island (West Nusa Tenggara) have been known as one of the sea turtle habitats(Monk and De Fretes, 2012). These small island chains contain great biodiversity of marine creatures and are endowed by an outstanding coastal area. Gili Matra refers to the three small island chains in western Lombok Island, consisting of Gili Trawangan, Gili Meno, and Gili Air. Technically, Gili Matra is an administrative area to refer single management principle of three small islands into one planning and development scenarios. Considering the important role of Gili Matra as habitat of numerous marine creatures and potential sites for nature recreation, Gili Matra was declared as a Marine Recreation Park Area (Taman Wisata Perairan TWP). The objective was to ensure that the tourism in Gili Matra area would contribute to the biodiversity conservation of the water ecosystem (Kurniawan, et al., 2016).

The development of a marine recreation park in Gili Matra is relevant to the increase of tourism activity in Lombok Island. Tourism in Lombok Island has been increased significantly, and the economic contribution of tourism has been recorded as significant in supporting local development. Natural resources are the ultimate resources of tourism in Lombok 
Island. The island has spectacular wide and long sandy coast. Tourism has been boosted by Lombok International Airport by supporting international tourist arrivals. Lombok Island has been designated as a tourism gateway in Lesser Sunda Islands (Soemodinoto and Wong, 2004; Badan Perencanaan Pembangunan Daerah Nusa Tenggara Barat, 2015; Hakim, et al., 2017).

The importance of Gili Matra as one of the crucial habitats for sea turtle nesting led to the designation of the area as a conservation area to support the global sea turtle conservation program. The sea turtle has been involved in Appendix 1 of the IUCN Red List, which represents the recent crucial status of the species in the future. The consumption of the sea turtle has led to a decrease in the sea turtle population. Other factor related to the decrease of the population was predator attack on sea turtle eggs and newly born turtles in the coastal area. There are also contributions of pollution that significantly contribute to the sea turtle health in the marine ecosystem (Seminoff, 2004; Wallace, et al., 2011).Considering the rapid population decrease and increase of threats, Indonesian government released Government Decree No.7 of year 1999 to declare the sea turtle as one of the protected species in the Indonesia territory.

The conservation and protection of sea turtle habitat has achieved success through the support of stakeholders. The position of stakeholders in sea turtle conservation was important. Stakeholders interested in biodiversity issues contribute to both negative and positive aspects. Threats to sea turtle often come from political, social, and economic aspects. The political aspect is often related to the regulation, which is often influenced by party interests. Parties that benefit from sea turtle as economic resources often support a weak policy in support of conservation. The socio-cultural aspect is often related to the belief systems. In many indigenous communities, the sea turtle was collected for traditional ceremonial purposes. In many cases, the sea turtle is material for medical treatment. The economic aspect is often related to the collection of the sea turtle to increase a household's income. In numerous studies, scholars point out that stakeholders are able to support biodiversity conservation, including the sea turtle and its habitat. Community participation is the key to numerous conservation programs (Formia, et al., 2003; Gjertsen and Niesten, 2010; Hakim, et al., 2012; Budiantoro, et al., 2019).

The sea turtle has gained serious attention among the global community due to its population decrease. It plays an important role in the marine ecosystem. Recent threats to the sea turtle have strengthened and are likely cause species' extinction in the future. For many conservation programs, lack of community and stakeholder involvement is the main problem, especially in developing countries. Stakeholder involvement, the process of inviting stakeholder participation in a conservation program, is an essential part of any conservation program. Scholars point out that few species can be conserved without stakeholder participation. High pressure of sea turtle population requires community participation in the sea turtle conservation program. The multi-stakeholder approach seems to be crucial in the conservation program (Kinan and Dalzell, 2005). To date, few studies are related to the stakeholder perception to support the sea turtle conservation program in Gili Matra. The aim of this research is to identify stakeholder perspectives of the sea turtle in the Gili Matra nature tourism area.

\section{Methods}

A field survey was conducted at Gili Matra. Ecologically, the Gili Matra area consists of three small islands, namely Trawangan, Gili Air, and Gili Meno. The waters of Gili Matra have been identified as rich in terms of marine creatures, ranging from invertebrates to vertebrates (Monk and De Fretes, 2012). Located in a tropical region with warm climates 
and a white sandy beach, these islands are the favourite tourist destinations. Nature-based tourism grows significantly, and it contributes significantly to provision of numerous works for local people in the Gili Matra area, Mataram City and other regions in Lombok (Hakim, et al., 2017).

To identify and describe the stakeholder perception of the sustainability of sea turtle conservation in the Gili Matra Tourism area, Focus group discussion and participatory mapping of the sea turtle distribution was implemented at Gili Indah Village at Pemenang Sub-Regency, Lombok Utara Regency. A field survey and a discussion were implemented in August to October 2017. Prior to the Focus Group Discussion (FGD), authors identified stakeholders in sea turtle conservation in Gili Matra through observation, literature study, and consultation with a local authority who has responsible in Gili Matra waters and island management.

\section{Focus group discussion}

Focus group discussion was used as an instrument to determine issues and perspectives on sea tur]tle conservation. FGD was done through a given focus topic discussion. The first step of FGD was initiated by the collection of information and participant perceptions related to the problem and opportunities in sea turtle conservation. The participant of the FGD was a natural group, that is, a group in which the participants were local actors who have a direct relationship with the Gili Matra ecosystem. The initial survey was conducted to identify potential stakeholders who have crucial positions and impacts in the sea turtle conservation program. This survey considered 20 local community members in Gili Matra who had been identified to have direct interaction with sea turtles as informants. These community members consisted of six persons from Gili Trawangan, six persons from Gili Meno, and six persons from Gili Air. The composition of informants was two fishermen, two people who were involved in the sea turtle conservation program in each island, two diving and snorkeling guides from each island, and two persons from the institute of BKKPN.

In this research, FGD was implemented to generate sea turtle conservation-related issues in ecological, social, and economic issues in Gili Matra ecosystem. The discussion was held to identify some crucial issues, including (1) participant knowledge about the sea turtle, (2) sea turtle distribution, and (3) factors related to sea turtle threats. The discussion was organized and led by the authors. FGD was implemented through systematic steps, namely (1) author introductions and explanation of the discussion mechanism, (2) introduction to the background of the study, (3) session for participant expressions on the themes of particular issues delivered by facilitators, (4) a general discussion and feedback, and (5) general conclusion. The general discussion was set up to drawn stakeholders' and local people's recommendations related to the conservation strategy in the Gili Matra area. Authors document data and information that were generated from the discussion.

\section{Participatory mapping}

Participatory mapping was conducted through discussion to describe past and recent distribution of sea turtles in Gili Matra. Totally, there was 20 participant in the participatory mapping. Participants comes from Gili Trawangan 6 participants, Gili Meno 6 participants, Gili Air 6 participants and 2 participant from local officers of Lombok Utara Regency. In each island, participants in this participatory mapping has various background, including fishermen, diving guides, sea turtle conservationists, and representatives of the local conservation office (BKKPN). Authors facilitated the participatory mapping by providing a map of the Gili Matra area and discussion material to describe sea turtle 
distribution. Discussion was implemented in Gili Trawangan village office in August 2017. Each representative of discussion was invited to draw the distribution of the turtle based on informants' direct contact experience with sea turtles in Gili Matra waters. During the discussion, there were possible corrections by other participants. The final map is the conclusion among informants. Data were analysed descriptively.

\section{Results and Discussion}

\section{Community knowledge about the sea turtle}

Four stakeholder groups in Gili Matra that are related to the sea turtle conservation program, namely primary group of stakeholders, secondary group of stakeholders, tertiary group of stakeholders, and external stakeholders. This classification was similar to that proposed by Suana and Ahyadi, (2012). Local fishermen are one of the important primary stakeholders in sea turtle conservation. This group has been identified as a group that are plays an important role in Gili Matra ecosystem management. Although fishermen have a close relationship with the ecosystem, sociopolitically local fishermen have a low position in many decisions related to the management of the water ecosystem. Other groups of stakeholders seem have the most influence in the management of sea waters. Some aspects were identified to contribute to a low bargaining position of local farmers. It is mainly related to the poor power of human resources, which is mainly caused by low educational levels. Informants point out that local fishermen have low authority and power to implement punishment to actors who are identified as contributing to the marine ecosystem disturbance and degradation.

\section{Sea turtle in Gili Matra waters}

Three species of the sea turtle have been identified and recognized in Gili Matra waters, including Chelonia mydas, Eretmochelys imbricata and Lepidochelys olivacea. Local people call Chelonia mydas as penyu hijau (the green sea turtle). Respondents could recognize Chelonia mydas from the morphological feature. Local people call Eretmochelys imbricata as penyu sisik (the hawksbill sea turtle). Respondents state that both Chelonia mydas and Eretmochelys imbricata are common and easily found in Gili Matra waters (Fig. 1). Previous research confirms that Gili Matra waters and their surrounding sea are the harbour for numerous marine creatures, ranging from invertebrates to vertebrates. In the past, it was reported that abundant coral reefs are the significant habitat that supports biodiversity in Gili Matra waters (Ali, et al., 2004; Monk and De Fretes, 2012). Respondents state that recently, Lepidochelys olivacea, locally known as penyu lekang (olive ridley sea turtle), had been difficult to find.There is no information related to the decrease and local extinction of the species in Gili Matra waters. 


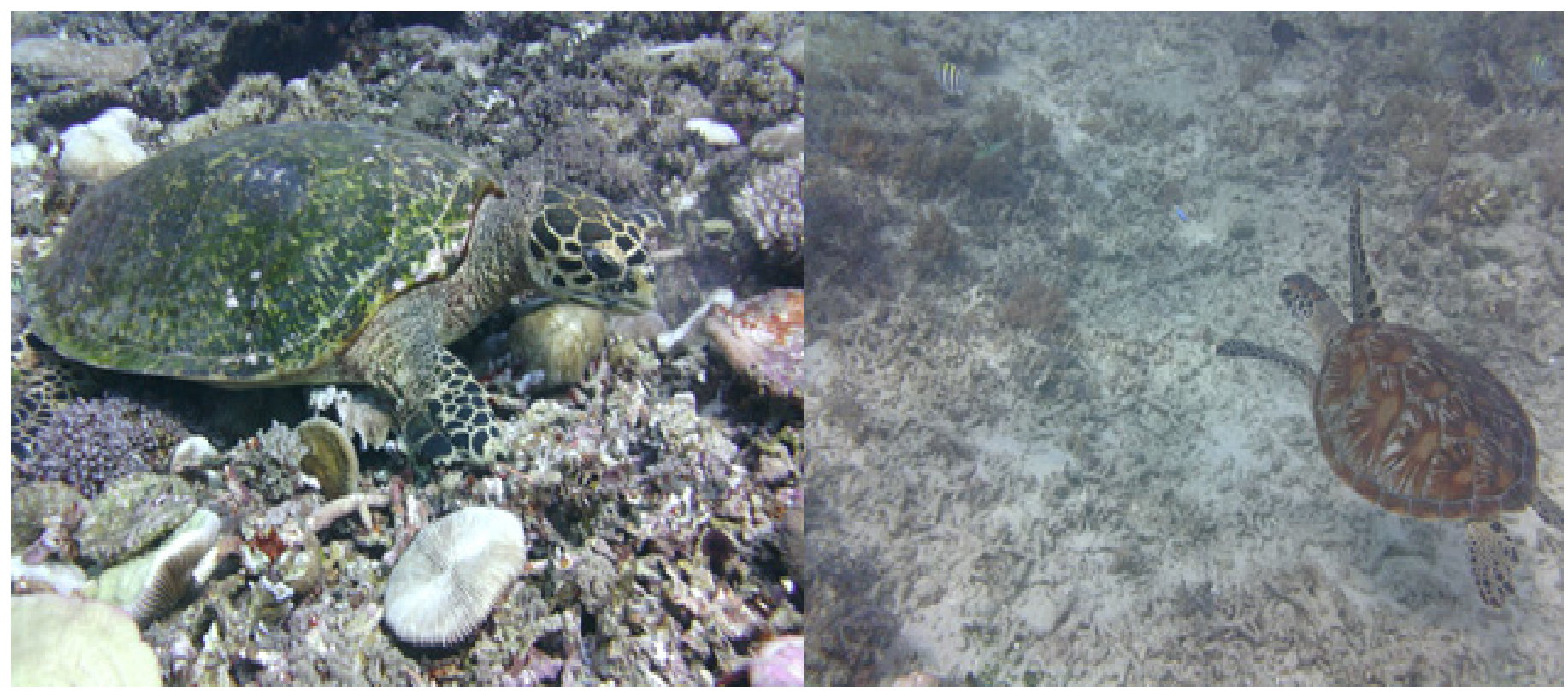

Fig 1. Two species of sea turtle that are easily found by local people in Gili Matra waters: Chelonia mydas, locally called Penyu Hijau (left), and Eretmochelys imbricata, locally called Penyu Sisik (right)

Informants point out that the sea turtle is an important marine reptile. The sea turtle was poached and sold in the black market to generate households' income. Informants point out that recent attention to the survival of the sea turtle in Gili Matra waters has increased as a consequence of marine pollution and human consumption. Some local and international agencies provide attention to the conservation of the sea turtle, including local NGOs, local universities, local government of Mataram and the Agency of Marine Conservation. There are also international NGOs that contribute to the conservation of the sea turtle. Informants also point out that efforts to conserve the sea turtle were numerous, ranging from basic research to describe the ecological aspect of the sea turtle to local community development.

\section{Number of sea turtles in Gili Matra}

From FGD, stakeholders said that the number of sea turtles in Gili Matra waters decreases yearly. Based on their observations through traditional diving and snorkelling techniques, fishermen report that between 1990 and 2000, the number of observed sea turtles in Gili Matra water ranged from 10 to 25 individuals. Between 2000 and 2010, the number of observed individuals was decreased to 5-15 individuals per report. From 2010 to recent years, the observed number was approximately $5-7$ individuals per report. These data indicate that direct observations by fishermen confirm that the sea turtle population decreases significantly in Gili Matra waters.

\section{Recent threats to the sea turtle}

Respondents state some humans contribute to the recent threats to the sea turtle population. There are no statements related to the contribution of natural aspects to the decrease of the sea turtle population in Gili Matra waters. Informants point out that human activity in Gili Matra waters contributes to the decrease of the sea turtle population. Basically, two factors contribute to decrease can be classified into two aspects: the quality of sea turtle habitat in the sea and the human aspect. 


\section{Decrease of habitat}

Respondents identified decrease of the sea turtle habitat. This decrease is caused by marine pollution and sandy coastal disturbance. Domestic waste is one of pollutants that were often observed in Gili Matra waters. There are no chemical indications reported by informants. The respondents could not state specifically the quality of the waters, but they believed the waters had been polluted. There is much scientific evidence in the tropical water that indicates that pollution has a significant effect on sea turtle survival.

In the land sites, the sandy coastal area in Gili Matra has been influenced by tourism activity, which contributes significantly to the reproduction cycle of sea turtles. Recently, the sandy coastal area in Gili Matra is one of the most attractive sites for coastal tourism activity. Various studies have demonstrated that with the increase of tourism activity in the coastal area, the vegetation structure of the sandy beach also changes. The decrease of the sandy coastal vegetation plays a major role in reduction of sandy soil's capability to support the sea turtle reproduction cycle in a natural habitat.

\section{Human impact}

Human pressure to the wild population of sea turtle comes from several aspects but is mostly associated to the consumptive needs. According to respondents, the decrease of the number of sea turtles in Gili Matra waters was caused by an increase in human consumption of the turtles. From FGD, it is clear that during 1900 to 2000, there was intensive sea turtle poaching by fishermen from Bali and Flores. The collected sea turtle was transferred and sold in Bali in illegal markets.

The decrease in the number of species in the Gili Matra marine tourism area was caused by an increase in sea turtle consumption. The informants report that the meat and eggs of the sea turtle were consumed, and in many cases, they had become an economical marine-based commodity. There were also reports of shell trading. Sea turtle catching has been carried out in many parts in the sea turtle nesting area in Indonesia. The need of meat from Bali was significant, leading to the illegal poaching of sea turtles in numerous areas in Indonesia that are identified as spots for the sea turtle population (Waayers, 2006).

Humans are the major threats to sea turtle sustainability, both in open marine and coastal areas. Informant report that sea turtle carapace export increased in 1967-1993. The highest carapace export was reported in 1978 in which 200,000 sea turtles were exported to Singapore, Japan, Korea, and Hong Kong.

\section{Distribution area of the sea turtle}

Sea turtles freely distribute in the open sea. In the situation where control is poor, it is difficult to monitor sea turtle poaching by humans. People often see sea turtle as open access resources, which are free to exploit. The sea turtle black market in Tanjung Benoa, Bali is an example for a complicated business that is not easy to stop. 


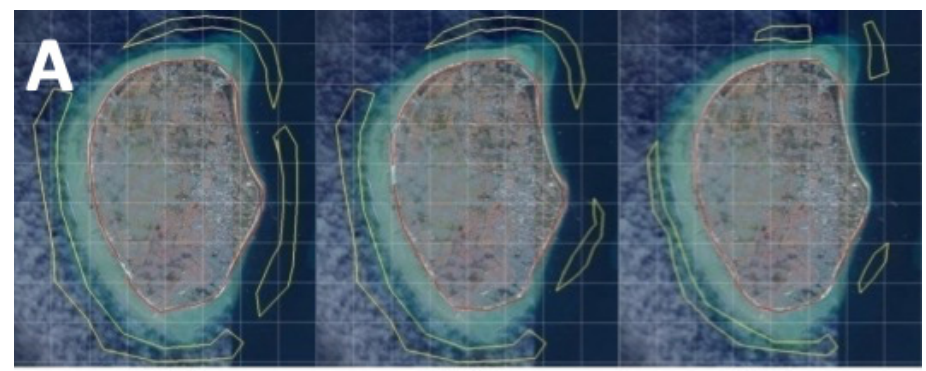

$$
<2000<2010 \quad>2010
$$

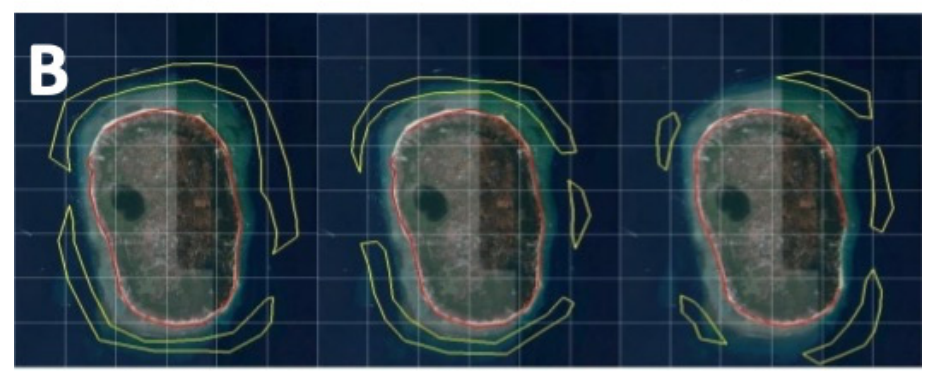

$$
<2000<2010 \quad>2010
$$

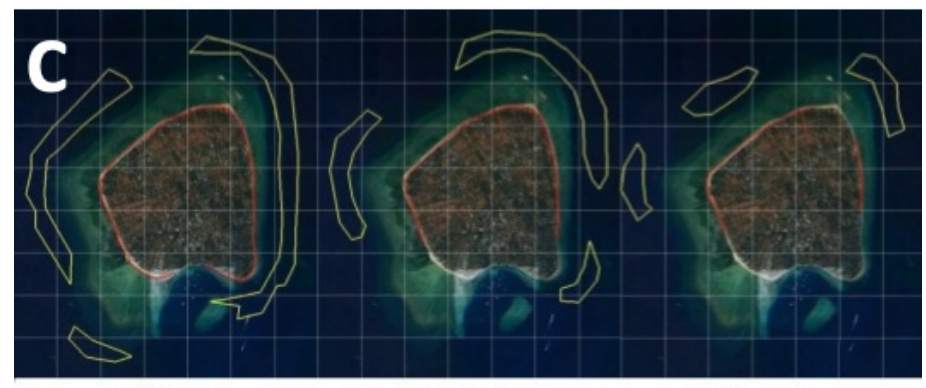

$<2000 \quad>2010 \quad>2010$

Fig 2. Habitat for the sea turtle in the Gili Matra area: A, Gili Trawangan Island; B, Gili Meno; and C, Gili Air.

The distribution of sea turtles in Gili Matra has been found to have decreased (Fig. 2). The informants reported and stated that before the 2000s, sea turtles in Gili Trawangan waters occupied an area of approximately $17,428 \mathrm{~m}^{2}$. From the Focus Group Discussion forum, the distribution was reported to decrease between 2000 and 2010 in which it is estimated that the distribution area was approximately 14,884 $\mathrm{m}^{2}$. A survey conducted in 2010 confirmed that the distribution area was approximately $13,713 \mathrm{~m}^{2}$. The similar trend has been found in Gili Meno waters. Between 1900 and 2000, it was reported that sea turtles were distributed over a 12,968 $\mathrm{m}^{2}$ area in Gili Meno waters. In 2010, the distribution decreased, as it was reported to be $11,321 \mathrm{~m}^{2}$. After 2010, the habitat of sea turtles was $8.158 \mathrm{~m}^{2}$. In Gili Air, before 2010 , sea turtles were reported to be distributed in an area of approximately $4.829 \mathrm{~m}^{2}$. The habitat was reported to increase in 2010, when the sea turtle distribution area was reported to be approximately $5,361 \mathrm{~m}^{2}$.

From focus discussion forum, nesting sites in the Gili Matra coastal area were also reported to have decreased. Before 2000, the nesting area in Gili Trawangan was approximately 8,774 $\mathrm{m}^{2}$. Between 2000 and 2010, the nesting area was approximately $6,198 \mathrm{~m}^{2}$. After 2010 , the nesting area was approximately $5,653 \mathrm{~m}^{2}$. A similar trend was also recorded in Gili Meno. In 1900-2000, the area for nesting was approximately 8,774 $\mathrm{m}^{2}$. In 2000 to 2010, it was 4,916 $\mathrm{m}^{2}$. After 2010, 
the nesting area was approximately $8,158 \mathrm{~m}^{2}$. In 1900-2000, the distribution area in Gili Air waters was recorded as $10,783 \mathrm{~m}^{2}$. In 2000 to 2010 , it was recorded as $3,329 \mathrm{~m}^{2}$. After 2010 , the nesting area was approximately $2,444 \mathrm{~m}^{2}$.

Rapid development of tourism in Gili Matra was mentioned as one of the critical factor for physical and social changes of the Gili Matra area. Field observation found some crucial problem in Gili Matra waters, including degradation of coral reefs, decrease of sandy beach aesthetics, coastal abrasion, and pollution. These environmental changes led to the survival of marine species, including the sea turtle. According to respondents, remote beaches with less tourism infrastructure facility development were preferred sites for nesting. Sea turtles prefer a flat beach area.

The FGD highlighted four aspects related to the decrease of the number of species of species and distribution area in Gili Matra. The aspects include (1) illegal catching, (2) decrease of the nesting area, (3) land use change, and (4) habitat degradation.

The field survey found beach degradation in the Gili Matra area. The main degradation was caused by beach abrasion. The main cause for beach abrasion was ocean wave and degradation of coral reefs in Gili Matra waters. In 2008, approximately $75 \%$ of coral reefs were degraded. The massive degradation was caused by coral exploitation, building materials, illegal fishing, El-Nino, and tourism. A previous survey indicated that contribution of human activity was significant (Suana and Ahyadi, 2012). Ecologically, the degradation of coral reef contributes significantly to the decrease of sea turtle population in Gili Matra waters. Scholars point out that coral reefs are the feeding area for sea turtles and are one of important places for the sea turtle's life cycle.

Decrease of beach habitat contributes significantly in nesting area performance. Beach degradation changes the beach morphology and leads to slope degree. Sea turtles prefer a flat beach, which is suitable for nesting activity(Budiantoro, et al., 2019). A study by Wood and Bjorndal (2000) confirmed that there are relations of physical attributes of a beach (i.e., temperature, moisture, salinity, and slope) to the nest site selection of sea turtles, especially loggerhead sea turtles.

According to the respondents, increase of tourism activity leads to the increase of transportation in the water ecosystem. The number of traditional boats and special boats for tourism increased significantly in Gili the Matra area. The impact of increasing boat transportation includes water pollution caused by oil and development of ports. Previous studies by Davenport \& Davenport (2006) pointed out that personal leisure transport has a significant impact on the coastal ecosystem.

Activities of fishermen who collect fish in coral reefs were also identified as threats to the sea turtle population. Unsustainable harvest of marine resources contributes to the sea turtle population decrease in Gili Matra waters. Fishermen report that many sea turtles are often found in the area where there is fish abundance and, therefore, an increase in the potentiality to catch them using fisherman's nets. The use of gillnet and trawl increases the risk of sea turtle disturbance in sea waters. Some fishermen illegally use dynamites, potassium, and poisons that are dangerous to the marine living system. These increase the risk of sea turtle decrease in Gili Matra waters. In the long run, if this continues to occur in Gili Matra waters, the population of sea turtles will decrease.

Tourism waste has been identified as a crucial factor of enhancement of the sustainability of small islands in the Gili Matra area. The abundance and poor waste management both in terrestrial and aquatic ecosystems contribute to the sea water quality, which contributes to the survival of marine creatures, including sea turtles. Previous research confirmed that Gili Air is an area with a large amount of domestic waste. It was reported that the amount of waste reached $505.78 \mathrm{~kg} /$ day. The domestic waste product from Gili Trawangan was 317,856 kg/days, whereas that from Gili 
Meno was $177,773 \mathrm{~kg} / \mathrm{h}$ (Hadi, et al., 2016). Marine pollutants, especially plastic, recently contribute significantly to the marine ecosystem (Derraik, 2002). Plastics are non-degradable materials, and in many case. they are reported to disturb marine creatures through numerous mechanisms. Without proper domestic waste management, the amount of plastic waste will increase significantly. Plastic waste contributes not only to the marine ecosystem but also, significantly, to the terrestrial habitat in Gili Matra as a tourism destination area.

Tourism in the Gili Matra area has recently grown significantly, and numerous tourism programs have been promoted. Many of the programs are related to the sea waters and coastal ecosystem use. Recent growth of the tourism industry has led to intensive use of the coastal area. The main tourism facilities, such as cottages, restaurants, parks, art shops, and other tourism amenities, were established and developed in the coastal area (Hakim, et al., 2017). Tourism is currently the magnet for people beyond Gili Matra come to Gili Trawangan and Gili Air to get jobs and benefits from the tourism industry. This leads to the increase of the number of people in the limited space in Gili Matra area. One of the problems with the abundance of people in a small island is the increase and abundance of domestic waste. Without proper management, waste is a crucial environmental problem that affects coastal ecosystem integrity.

Since 2019, the area of Gili has been declared as a national tourism destination area. The main tourism attraction in the western part of Lombok was three small three islands, including Gili Trawangan, Gili Meno, and Gili Air. According to a provincial document, Gili Matra is the icon for sustainable tourism sites in Lombok, with the sea turtle as the most interesting tourism object. The increase of tourism activity in the Gili Matra area influences the rapid development of tourism infrastructure and facilities, especially in the coastal area. The development of tourism infrastructure and facilities in the coastal area was potentially occurs beyond the area designated for development. Poor control and commitment to following land use planning and slow development led to the development of many cottages disturbing the native area, which is important for sea turtle landing and nesting.

\section{Stakeholder recommendations}

From the FGD, some recommendations were proposed by the community and stakeholders to support the turtle conservation program in Gili Matra. These recommendations include:

1. Enhancing socialization and the campaign related to the role of sea turtles in the marine ecosystem. It is important to inform and disseminate regulation related to sea turtle conservation. There are national and local regulations related to sea turtle conservation. Stakeholders and community members who attended the FGD committed to support the sea turtle campaign though numerous media and facilities. The use of social media has recently become important for promotion of sea turtle conservation and delivery of the message about the value of sea turtles and marine ecosystem conservation in Gili Matra. Gili Indah villages have established village Regulation No. 3, year 2014, about coastal management and marine ecosystem in the Gili Indah area. In principle, such village regulation proposes a zoning system for spatial management to ensure sustainable use of natural resources in Gili Indah.

2. It is important to devise tools and facilities to support conservation action, including sigh boards and interpretation boards. Signboards should provide information related to habitat protection. In the field, it is often observed that the nesting habitat of sea turtles is disturbed by tourist activity because there are no signboards. 
People awareness to the crucial sites for sea turtle habitat was also found to be low since there are no interpretation boards.

3. It is important to control and stop the unsustainable practice of fish collection, especially the use of gillnet and trawl, potassium and other techniques that are dangerous to sea turtles and other marine creatures. The coordination among police, provincial offices for fisheries, the office for nature conservation, local government, local community groups, and other stakeholders should be enhanced to minimize illegal harvesting practices in the Gili Matra area. In Chapter 5 of Local Regulation related to Marine Resources Protection, there are declaration of catch, collect, and disturb sea turtle. Fishermen are prohibited to sell and consume sea turtles, manta ray, shark, and dolphins.

4. Strengthening the implementation of regulations. To date, regulations have been made, but their implementation is poor. Commitment among stakeholders is important. The routine and scheduled meeting among stakeholders should be implemented, and any problems should be solved comprehensively.

5. Providing training and technical assistance to the local community and the local office. One of the limitations of the sea turtle and marine ecosystem conservation program in the Gili Matra area is poor human resources.

\section{Conclusion}

Three species of sea turtle were found in TWP Gili Matra: Chelonia mydas, Eretmochelys imbricate, and Lepidochelys olivacea. There is a trend of sea turtle population decrease in Gili Matra waters. Observed and reported sea turtle landing areas decrease significantly. Some factors that contribute to the decrease of population have been identified, including (1) illegal poaching, (2) habitat decrease, (3) environmental pollution, and (4) land use changes.

To support sea turtle and marine biodiversity conservation programs, some recommendations were drawn. The recommendations include enhancing socialization and campaigns, providing tools and facilities to support fish conservation, controlling unsustainable practice of fish collection, strengthening the implementation of regulation, and providing training and technical assistance to the local community and the local office.

\section{References}

Ali, A., Talib, Z., Yaacob, K.K.K., 2004. Sea turtle species of the Southeast Asian countries. Marine Fishery Resources Development and Management Department, Southeast Asian Fisheries Development Center.

Badan Perencanaan Pembangunan Daerah Nusa Tenggara Barat, 2015. Rencana Induk Pariwisata Berkelanjutan Pulau Lombok 2015-2019, Mataram.

Barr, C., 2001. Current status of trade and legal protection for sea turtles in Indonesia. Marine Turtle Newsletter, 54: 4-7.

Budiantoro, A., Retnaningdyah, C., Hakim, L., Leksono, A.S., 2019. The Characteristics of olive ridley sea turtle (Lepidochelys olivacea) nesting beaches and hatcheries in Bantul, Yogyakarta, Indonesia. Biodiversitas Journal of Biological Diversity, 20(11): 3119-3120.

Chaloupka, M., Dutton, P., Nakano, H., 2004. Status of sea turtle stocks in the Pacific. FAO Fisheries Report, (738): 135-164.

Davenport, J., Davenport, J. L., 2006. The impact of tourism and personal leisure transport on coastal environments: a review. Estuarine, Coastal and Shelf Science, 67(1-2): 280-292.

Derraik, J. G., 2002. The pollution of the marine environment by plastic debris: a review. Marine Pollution Bulletin, 44(9): 842-852. 
Formia, A., Tiwari, M., Fretey, J., Billes, A., 2003. Sea turtle conservation along the Atlantic coast of Africa. Marine Turtle Newsletter, 100(1): 3337.

Gjertsen, H., Niesten, E., 2010. Incentive-based approaches in marine conservation: applications for sea turtles. Conservation and Society, 8(1): 5-14.

Hadi, S., Ahyadi, H., Suana, I.W., 2016. Jenis dan Kapsistas Timbulan Sampah di TWP Gili Matra. Jurnal Biologi Wallacea, 2 (1): $23-30$.

Hakim, L., Soemarno, M., Hong, S.K., 2012. Challenges for conserving biodiversity and developing sustainable island tourism in North Sulawesi Province, Indonesia. Journal of Ecology and Environment, 35(2): 61-71.

Hakim, L., Ahyadi, H., Hong, S.K., 2017. Exotic plant in small islands: implications for tourism destination management in Gili Trawangan and Gili Air, Lombok. Journal of Marine and Island Culture, 6(1):1-64.

Hakim, L., 2017. Managing biodiversity for a competitive ecotourism industry in tropical developing countries: new opportunities in biological fields. In AIP Conference Proceedings (Vol. 1908, No. 1, p. 030008). AIP Publishing LLC.

Halim, M. H., Silalahi, S., Sugarjito, J., 2001. Conservation and utilization trend of marine turtles in Indonesia. Tigerpaper (FAO), $28: 10-18$.

Kinan, I., Dalzell, P., 2005. Sea turtles as a flagship species. Maritime Studies (MAST), 3(2): 195-212.

Kurniawan, F., Adrianto, L., Bengen, D. G., Prasetyo, L.B., 2016. Patterns of landscape change on small islands: A case of Gili Matra Islands, Marine Tourism Park, Indonesia. Procedia-Social and Behavioral Sciences, 227: 553-559.

Mack, D., 1983. Worldwide trade in wild sea turtle products: an update. Marine Turtle Newsletter, 24: 10-15.

Monk, K., De Fretes, Y., 2012. Ecology of Nusa Tenggara. Tuttle Publishing.

Nuitja. I.N.S., 1992. Biologi dan Ekologi Pelestarian Penyu Laut. Institut Pertanian Bogor Press, Bogor.

Rene, M.M., 1990. FAO Species Catalogue Vol.11 Sea Turtles of the World. An annotated and illustrated catalogue of sea turtle species known to date, FAO Fisheries Synopsis No. 125, volume 11, Rome.

Seminoff, J.A., 2004. Sea turtles, red listing, and the need for regional assessments. Marine Turtle Newsletter, 106: 4-6.

Shanker, K., Pilcher, N.J., 2003. Marine turtle conservation in South and Southeast Asia: hopeless cause or cause for hope. Marine Turtle Newsletter, 100, 43-51.

Soemodinoto, A., Wong, P.P., 2004. Patterns and processes of tourism development on the Gili islands, Lombok, Indonesia. ASEAN Journal on Hospitality and Tourism, 3(2): 77-89.

Suana, I. Wayan, Hilman A., 2012. Mapping of Ecosystem Management Problems in Gili Meno, Gili Air, and Gili Trawangan (Gili Matra). Through Participative Approach, Coastal Development Journal, 16(1): 94-101.

Suganuma, H., Yusuf, A., Bakarbessy, Y., Kiyota, M., 2005. New leatherback conservation project in Papua, Indonesia. Marine Turtle Newsletter, 109:1-8.

Waayers, D., 2006. Potential for developing marine turtle tourism as an alternative to hunting in Bali, Indonesia. Indian Ocean Turtle Newsletter, 4:12-14.

Wallace, B.P., DiMatteo, A.D., Bolten, A.B., Chaloupka, M.Y., Hutchinson, B.J., Abreu-Grobois, F.A., Bourjea, J., 2011, Global conservation priorities for marine turtles. PloS one, 6(9), e24510.

Wood, D.W., Bjorndal, K.A., 2000. Relation of temperature, moisture, salinity, and slope to nest site selection in loggerhead sea turtles. Copeia, 2000(1), 119-119. 